\title{
Struktur Komunitas Semut (Hymenoptera : Formicidae) di Lahan Pertanian Organik dan Anorganik Desa Batur, Kecamatan Getasan, Kabupaten Semarang
}

\author{
Ivan Mahadika Putra, Mochamad Hadi dan Rully Rahadian \\ Laboratorium Ekologi dan Biosistematik, Departemen Biologi \\ Fakultas Sains dan Matematika, Universitas Diponegoro, Semarang \\ Jln. Prof. Soedarto, SH., Tembalang, Semarang, 50275, Telp: (024) 747454; Fax: (024) 7474754 \\ Email : ivanmahadika45@gmail.com
}

\begin{abstract}
Ants play an important role in terrestrial ecosystems, including in organic and inorganic farmland, as predators, scavengers, and their interaction with other organism. The objectives of this study were to compare the community structure and the role of the ant in organic and inorganic farmland, and also to determine soil abiotic factors in both farmland. The study was conducted in organic and inorganic chili crop land at Batur village, Getasan, Semarang. The sampling of ants was performed using pitfall traps and bait traps, and then the ants were identified. Data analysis used is an abundance index, diversity index, evenness index, Hutchinson test and similarity index. The results showed that the number of species and the number of individual of ants in organic farm were higher ( 45 individuals, 8 species) than inorganic farm (35 individuals, 6 species). Diversity index of ant species in both farmlands were categorized moderate with the index value of 1.92 and 1.42. Statistically, there were no significant differences in species diversity of ants in organic and inorganic farmland. There were five dominant species in organic field and three dominant species in inorganic field. Ants that predominate in both farmlands were Iridomyrmexsp, Tetramorium $s p$, Solenopsisgeminata, Odontoponeradenticulata and Diacammasp. The similarity of ant communities between organic and inorganic farmland showed high value of similarity index (IS) which was $85.7 \%$. Statistically, abiotic factors showed that there were significantly different of some abiotic factors in both farmlands, the content of carbon, phospor, organic matter and $\mathrm{c} / \mathrm{n}$ ratio.
\end{abstract}

Keywords: community structure of ants, agricultural ecosystems

\begin{abstract}
Abstrak
Semut berperan penting di ekosistem terestrial, termasuk di lahan pertanian organik maupun anorganik. sebagai predator, pemakan bangkai, dan interaksinya dengan organisme lain. Penelitian ini bertujuan unuk membandingkan struktur komunitas dan peran semut di lahan pertanian organik dan anorganik serta membandingkan faktor abiotik di lahan organik dan anorganik. Penelitian dilakukan di lahan pertanian cabe organik dan anorganik di Desa Batur, Getasan, Kabupaten Semarang. Sampling semut dilakukan menggunakan metode pitfall trap dan bait trap untuk kemudian dilakukan identifikasi. Hasil menunjukkan bahwa jumlah jenis dan jumlah individu semut yang diperoleh di lahan pertanian organik lebih tinggi (45 individu, 8 jenis) dibandingkan lahan anorganik ( 35 individu, 6 jenis). Indeks keanekaragaman jenis semut di lahan pertanian organik dan anorganik dikategorikan sedang dengan nilai indeks 1.92 dan 1.42. Secara statistik, tidak ditemukan perbedaan yang nyata keanekaragaman jenis semut di lahan pertanian organik dan anorganik. Terdapat 5 spesies dominan di lahan organik dan 3 spesies dominan di lahan anorganik. Semut yang mendominasi di kedua lahan yaitu Iridomyrmex sp, Tetramorium sp , Solenopsis geminata, Odontoponera denticulata dan Diacamma sp. Kesamaan komunitas semut antara lahan pertanian organik dan anorganik menunjukkan nilai indeks kesamaan (IS) yang tinggi yaitu $85.7 \%$. Secara stasistik, kandungan unsur yang berbeda pada kedua lahan adalah unsur karbon, fosfor, bahan organik dan rasio $\mathrm{c} / \mathrm{n}$
\end{abstract}

Kata kunci : struktur komunitas semut, lahan pertanian.

\section{PENDAHULUAN}

Indonesia merupakan negara agraris dengan mata pencaharian penduduknya sebagian besar sebagai petani. Pertanian merupakan salah satu kegiatan yang memanfaatkan sumber daya alam hayati untuk menghasilkan kebutuhan pokok 
pangan dan meningkatkan taraf pendapatan masyarakat (Sutanto, 2002). Sejauh ini di dalam sektor pertanian dikenal dengan dua macam sisten tanam, yaitu sistem pertanian organik dan sistem pertanian anorganik.

Sistem pertanian anorganik merupakan pertanian yang menggunakan pestisida dan pupuk kimia sintetik (Sutanto, 2002). Hal ini dikarenakan berkembangnya berbagai jenis hama dan penyakit pada tanaman. Matsumura (1976) mengatakan bahaya yang ditimbulkan oleh residu pestisida bukan hanya dapat membunuh hama, tetapi juga dapat membunuh agen lain seperti musuh musuh alami, ikan, dan lain- lain yang bukan menjadi target.

Musuh alami serangga terbagi menjadi dua yaitu parasitoid dan predator. Semut termasuk merupakan serangga musuh alami yang berperan sebagai predator. Semut merupakan serangga yang tergolong ordo Hymenoptera dan famili Formicidae yang memiliki jumlah jenis dan populasi yang berlimpah (Bolton, 1994). Semut termasuk kedalam serangga predator karena sifatnya aktif dan kuat serta memangsa serangga yang lebih kecil dan lemah.

Perang semut di alam dapat memberikan pengaruh positif dan negatf terhadap hewan dan juga manusia. Manfaat positif tidak dapat secara langsung dinikmati oleh manusia misalnya peran sebagai predator, menguraikan bahan organik, mengendalikan hama dan bahkan membantu penyerbukan (Rianto, 2007). Semut dapat dijadikan sebagai predator untuk menanggulangi hama di perkebunan. Rossi dan Fowler (2002) melaporkan bahwa Solenopsis sp di Brazil dapat dimanfaatkan sebagai agen pengontrol kepadatan larva Diatraea saccharalis, penggerek tanaman tebu.

Keberadaan semut di ekosistem terestrial sangat melimpah dan memiliki peran pada lahan pertanian diantaranya adalah dapat memperbaiki sifat fisik dan kimia tanah. Proses dekomposisi dalam tanah tidak akan mampu berjalan dengan cepat bila tidak ditunjang oleh kegiatan makofauna tanah salah satunya yaitu semut.

Penelitian mengenai semut ini dapat membantu untuk mengetahui peranannya di lahan pertanian dan keanekaragaman komunitas. Oleh karena itu, mengingat jumlah individu yang berlimpah dan perannya yang sangat penting bagi lahan pertanian, maka perlu dilakukan penelitian mengenai struktur komunitas semut yang ada di lahan pertanian. Penelitian dilakukan di Desa Batur, Kecamatan Getasan, Kabupaten Semarag.

Adapun tujuan dari penelitian ini adalah 1) membandingkan struktur komunitas semut yang ada di lahan pertanian organik dan anorganik Desa Batur, Kecamatan Getasan, Kabupaten Semarang, 2) membandingkan faktor abiotik yang ada di lahan pertanian organik dan anorganik.

\section{BAHAN DAN METODE Waktu dan Tempat}

Penelitian dilaksanakan pada bulan Oktober hingga Desember 2016. Lokasi pengambilan sampel bertempat di lahan pertanian organik dan anorganik Desa Batur, Kecamatan Getasan, Kabupaten Semarang. Lahan pertanian organik berukuran $27 \times 6 \mathrm{~m}^{2}$ dan lahan anorganik berukuran $22 \times 7 \mathrm{~m}^{2}$. Komoditas yang berada di lahan pertanian organik dan anorganik adalah tanaman cabe. Lokasi penelitian memiliki ketinggian \pm 1300 mdpl. Proses identifikasi sampel dilakukan di laboratorium Ekologi dan Biosistematik, Departemen Biologi, Fakultas Sains danMatematika, Universitas Diponegoro (UNDIP).

\section{Alat dan Bahan}

Alat yang digunakan dalam penelitian ini yaitu botol aqua gelas, $\mathrm{pH}$ soil tester, higrometer, termometer, kamera, mikroskop digital, botol sampel, meteran, alat tulis, buku identifikasi dan hand counter. Bahan yang digunakan dalam penelitian ini yaitu kapas, air gula, air deterjen dan alkohol 70\%.

\section{Cara Kerja}

Penentuan stasiun dan pengambilan sampel diakukan dengan metode teknik purposive sampling. Kriteria yang telah ditentukan yaitu digunakan dua stasiun yang merupakan lahan pertanian, dengan dua sistem pertanian yang berbeda.Pengambilan sampel pada kedua lahan dilakukan dengan menggunakan bantuan petak diagonal berukuran $4 \times 4 \mathrm{~m}^{2}$ sehingga ditentukan lima titik pengambilan sampel. Mengacu pada penelitian Wang et al.,(2015) di lahan pertanian dengan pola tanam tanaman yang homogen memudahkan dalam penentuan petak sampling dengan metode petak diagonal. 
Pengambilan sampel dilakukan dengan menggunakan metode Pit Fall trap dan Bait trap. Pit Fall Trap ditanam sejajar dengan permukaan tanah pada pukul 06.00 WIB - 06.00 WIB hari berikutnya, sedangkan Bait trap berasal dari kapas yang dicelupkan ke dalam air gula. Perangkap Bait Trap diletakkan diatas tanah pada pukul 07.00 WIB - 09.00 WIB.Sampel semut yang didapatkan dengan metode bait trap dan pit fall trap kemudiandimasukkan kedalam botol sampel dan diberi label.

Faktor lingkungan yang diukur berupa faktor fisik dan kimia. Faktor fisik meliputi suhu udara, suhu tanah, kelembaban udara, kelembaban tanah, $\mathrm{pH}$ tanah dan intensitas cahaya, sedangkan faktor kimia tanah meliputi kandungan unsur karbon, nitrogen, phospor, rasio c/ndan bahan organik di lahan pertanian organik dan anorganik.

\section{Analisis Data}

Analisis data dihitung dengan menggunakan indeks kelimpahan jenis, indeks keanekaragaman Shannon-Wiener, kemerataan Evennes, uji tHutchinson, indeks kesamaan Sorenson dan uji t-2 sampel independen.

\section{HASIL DAN PEMBAHASAN}

Hasil penelitian didapatkan jumlah semut yang tertangkap dengan menggunakan pit fall trap dan bait trap pada lahan pertanian organik memiliki jumlah individu dan jumlah jenis yang lebih tinggi dibandingkan lahan anorganik. Semut yang tertangkap dengan menggunakan pit fall trap memiliki jumlah individu yang lebih sedikit dibandingkan semut yang tertanggkap dengan bait trap, namun semut yang tertangkap dengan pit fall trap memiliki jumlah jenis yang lebih banyak dibandingkan dengan semut yang tertangkap dengan menggunakan bait trap.Penggunaan metode bait trap, umpan yang digunakan untuk menarik kehadiran semut adalah larutan gula, sehingga semut yang terambil dengan menggunakan bait trap adalah semut yang memiliki ketertarikan dengan gula seperti Iridomyrmex sp.

Semut Iridomyrmex sp yang tertangkap dengan menggunakan bait trap memiliki jumlah individu yang lebih banyak dibandingkan dengan semut lain yang tertangkap dengan menggunakan bait trap. Hal ini menunjukkan bahwa semut Iridomyrmex sp merupakan semut yang memiliki ketertarikan dengan makanan yang manis seperti cairan gula atau embun madu yang berasal dari kutu daun (Aphid sp). Menurut Wilson (2010) semut yang termasuk kedalam subfamili Dolichoderinae pada umumnya sebagai pemakan bangkai, predator dan memakan embun madu yang berasal dari kutu daun (Aphids sp).

Tabel 4.Indeks keanekaragaman, indeks kemerataan, jumlah individu dan jumlah jenis semut dengan menggunakan metode PitFall Trap di lahan organik dan anorga

\begin{tabular}{llcc}
\hline \multirow{2}{*}{ Subfamili } & \multicolumn{1}{c}{ Spesies } & \multicolumn{2}{c}{ LahanPertanian } \\
\cline { 3 - 4 } Dolichoderinae & Iridomyrmex sp & Organik & Anorganik \\
& Tapinoma melanocephalum & 2 & 16 \\
Formicinae & Camponotus sp & 4 & 0 \\
Myrmicinae & Solenopsis geminata & 5 & 2 \\
Ponerinae & Tetramorium sp & 10 & 2 \\
& Diacamma sp & 6 & 6 \\
& Leptogenys sp & 2 & 1 \\
\hline Jumlah Individu (N) & 8 & 0 \\
Jumlah Spesies (S) & 49 & 85 \\
Indeks Keanekaragaman (H') & 8 & 6 \\
Indeks Kemerataan (e) & 1,92 & 1,42 \\
& 0,92 & 0,79
\end{tabular}


Tabel 4.Jumlah individu dan jumlah jenis semut yang tertangkap dengan menggunakan Bait Trap di lahan pertanian organik dan anorganik

\begin{tabular}{llcc}
\hline \multirow{2}{*}{ Subfamili } & \multirow{2}{*}{ Spesies } & \multicolumn{2}{c}{ Lahan Pertanian } \\
\cline { 3 - 4 } & & Organik & Anorganik \\
\hline Dolichoderinae & Iridomyrmex sp & 74 & 43 \\
Myrmicinae & Tetramorium sp & 2 & 0 \\
Ponerinae & Diacamma sp & 78 & 2 \\
\hline \multicolumn{2}{c}{ Jumlah Individu } & 3 & 45 \\
\hline
\end{tabular}

Lahan pertanian organik memiliki 5 jenis semut yang termasuk kedalam kategori dominan yaitu Iridomyrmex sp, Diacamma sp, Solenopsis geminata, Tetramorium $\mathrm{sp}$ dan Odontoponera denticulata, sedangkan pada lahan pertanian anorganik terdapat 3 jenis semut yang termasuk dominan yaitu Iridomyrmex sp, Tetramorium $\mathrm{sp}$ dan Odontoponera denticulata. Semut yang masuk kedalam kategori subdominan pada lahan organik yaitu Tapinoma melanocephalu dan Leptogenys sp, sedangkan pada lahan anorganik terdapat 3 jenis yang termasuk kategori subdominan yaitu Camponotus sp, Solenopsis geminata, dan Diacamma sp.
Semut Iridomyrmex sp ditemukan melimpah di lahan pertanian. Kelimpahan semut Iridomyrmex sp pada lahan pertanian terkait dengan ketersediaan pakan yaitu embun madu yang berasal dari kutu daun. Interaksi yang dilakukan oleh semut Iridomyrmex sp dengan kutu daun (Aphid sp) merupakan interaksi interspesies dimana kutu daun akan mendapatkan perlindungan oleh semut Menurut Wilson (2010) semut yang termasuk kedalam subfamili Dolichoderinae selian berperan sebagai predator, juga memiliki ketertarikan dengan makanan yang manis seperti embun madu yang berasal dari kutu daun.

Tabel 4. Kelimpahan jenis semut pada lahan pertanian organik dan anorganik

\begin{tabular}{llcc}
\hline \multirow{2}{*}{ Subfamili } & \multicolumn{1}{c}{ Spesies } & \multicolumn{2}{c}{ Lahan Pertanian } \\
\cline { 3 - 4 } & & Organik \% & Anorganik \% \\
\hline Dolichoderinae & Iridomyrmex sp & $24.5(* *)$ & $46(* *)$ \\
& Tapinoma melanocephalum & $4.1(*)$ & 0 \\
Formicinae & Camponotus sp & $8.7(*)$ & $5.7(*)$ \\
Myrmicinae & Solenopsis geminata & $10.2(* *)$ & $5.7(*)$ \\
& Tetramorium sp & $20.4(* *)$ & $17.1(* *)$ \\
Ponerinae & Diacamma $\mathrm{sp}$ & $12.2(* *)$ & $3(*)$ \\
& Leptogenys sp & $4.1(*)$ & 0 \\
& Odontoponera denticulata & $16.3(* *)$ & $23(* *)$ \\
\hline
\end{tabular}
Ket : Taksa Dominan
Taksa Subdominan : Di 3,3\%-9,9\%(*)

Solenopsis geminata pada lahan pertanian organik termasuk kedalam jenis yang dominan. Solenopsis geminata merupakan semut tramp yang mampu beradaptasi pada habitat dengan aktivitas manusia. Aktivitas semut tramp juga mengakibatkan semut lain berkurang dikarenakan kalah berkompetisi mendapatkan makanan.
Menurut Holway et al., (2002) keberadaan semut tramp yang bersifat invasif seperi Anoplolepis gracilipes (Smith), Paratrechina longicornis (Latreille), dan Solenopsis geminata (Fabriscus) disamping mampu beradaptasi pada habitat terganggu juga dapat mengakibatkan hilangnya spesies semut yang lain karena kalah berkomptisi.Solenopsis geminata pada lahan 
anorganik termasuk kedalam kategori subdominan, hal ini dimungkinkan karena adanya pengaruh dari peaplikasian pestisida sintetik yang dapat membunuh serangga non target termasuk semut.

Semut Tetramorium sp termasuk ke dalam kategori dominan pada kedua lahan.Tetramorium sp memiliki kemampuan untuk menyebar dan beradaptasi pada berbagai tipe habitat termasuk disekitar pemukiman manusia serta tersedianya pakan berupa serangga lainnya. SemutTetramorium sp memiliki kasta pekerja mencapai 4000 ekor perkoloni sehingga menjadikan semut memiliki kemampuan hidup yang tinggi (Latumahina, 2014).

Odontoponera denticulata termasuk kedalam kategori dominan pada lahan organik dan anorganik. Odontoponera denticulata merupakan semut yang dapat beradaptasi pada habitat yang terdapat aktivitas manusia. Odontoponera denticulata banyak ditemukan pada daerah terganggu atau daerah yang banyak aktivitas manusia (Apriyanto, 2016).

Leptogenys sp dan Tapinoma melanocephalumtermasuk kedalam kategori subdominan di lahan pertanian organik. Tapinoma melanocephalum cenderung berada pada struktur bangunan yang dibuat oleh manusia sehingga menjadikan semut ini jarang di jumpai pada lahan pertanian (Astuti et al, 2014). Leptogenys sp merupakan semut yang hanya di jumpai pada hutan dengan ketinggian diatas 1000 mdpl dengan keberadaan isopoda sebagai makanannya. Leptogenys sp dapat ditemukan melimpah di beberapa area, mereka biasanya ditemukan di tempat yang lembab ataupada tempat dengan keberadaan isopoda yang melimpah sebagai makanannya (Lattke, 2011).

\section{Keanekaragaman Jenis Semut}

Indeks keanekaragaman pada lahan organik memiliki nilai yang lebih tinggi dibandingkan keanekaragaman pada lahan anorganik (Tabel 4.1). Rendahnya nilai indeks keanekaragaman pada lahan pertanian anorganik dikarenakan adanya pengaruh dari aplikasi pestisida yang digunakan. Pestisida yang diaplikasikan di lahan anorganik dapat mengakibatkan berkurangnya jenis dan jumlah individu serangga pada lahan tersebut. Menurut Hadi dkk., (2014) pada ekosistem sawah organik, keanekaragaman arthropoda tanah juga cenderung lebih tinggi dibandingkan pada sawah anorganik, hal ini dikarenakan masih adanya penggunaan pestisida dan pupuk kimia sintetik pada sawah anorganik yang mengakibatkan kematian dan perpindahan arthropoda tanah pada sawah anorganik.

Menurut Samudra (2013) mengatakan tingginya keanekaragaman menunjukkan ketersediaan sumber energi makanan yang baik. Keberadaan unsur dan bahan organik menjadi salah satu faktor rendahnya keanekaragaman semut pada lahan anorganik. Bahan organik akan dimanfaatkan oleh fauna tanah sebagai sumber energi. Semut menyukai daerah dengan kandungan bahan organik yang tinggi, dikarenakan dengan jumlah bahan organik yang tinggi maka akan mempengaruhi keberadaan fauna tanah yang merupakan makanan bagi semut. Untuk menguji perbedaan keanekaragaman semut antara lahan organik dan anorganik maka dilakukan uji Hutchinson. Perhitungan uji Hutchinson menunjukkan hasil yang tidak signifikan. Nilai t hitung $=1,312<1,663$ dibandingkan pada $t$ tabel dengan alpha 0,05 . Hal ini menunjukkan bahwa keanekaragaman pada lahan organik dan anorganik tidak berbeda nyata.

\section{Kemerataan Jenis Semut}

Nilai indeks kemerataan semut di lahan pertanian organik dan anorganik adalah 0,92 dan 0,79 . Nilai indeks kemerataan pada lahan pertanian organik dan anorganik termasuk kedalam kategori merata, menurut Fachrul (2007) persebaran jenis merata apabila memiliki nilai indeks kemerataan $>$ $0,6-1$

\section{Kesamaan Jenis Semut}

Indeks kesamaan jenis digunakan untuk membandingkan jenis semut yang ada pada masingmasing habitat. Hasil indeks kesamaan jenis pada lahan organik dan anorganik yaitu 85,7 \%. Nilai indeks kesamaan yang tinggi ini menunjukkan pada kedua lahan tersebut banyak terdapat jenis semut yang sama. Jarak kedua lokasi penelitian yaitu \pm $500 \mathrm{~m}$, sehingga faktor lingkungan yang ada pada kedua lahan cenderung sama. Menurut Mc Couley (2006), keberadaan spesies pada suatu struktur komunitas dibedakan oleh jarak, jenis habitat dan faktor fisik yang membatasinya. 


\section{Faktor Fisik dan Kimia Lingkungan}

Keberadaan semut pada suatu habitat bergantung pada faktor lingkungan yang ada disekitarnya. Faktor lingkungan dapat berupa faktor fisik maupun faktor kimia. Faktor kimia meliputi ketersediaan unsur dalam dalam seperti karbon, nitrogen, fosfor dan bahan organik, sedangkan faktor fisik seperti suhu, kelembaban, intensitas cahaya dan $\mathrm{pH}$.

Tabel. 4. Faktor fisik pada lahan organik dan anorganik

\begin{tabular}{lcc}
\hline \multicolumn{1}{c}{ Faktor Fisik } & \multicolumn{2}{c}{ Lahan Pertanian } \\
\cline { 2 - 3 } \multicolumn{1}{c}{ Lingkungan } & Organik & Anorganik \\
\hline Suhu Udara $\left({ }^{\circ} \mathrm{C}\right)$ & 28 & 26,5 \\
Suhu Tanah $\left({ }^{\circ} \mathrm{C}\right)$ & 26,8 & 24,5 \\
pH Tanah & 6,2 & 6,4 \\
RH Udara (\%) & 61 & 64 \\
RH Tanah (\%) & 38 & 43 \\
Intensitas Cahaya & 1555 & 1459 \\
(lux) & 1375 & 1331 \\
Elevasi (mdpl) & & \\
\hline
\end{tabular}

Pada penelitian kali ini, suhu udara dan suhu tanah pada lahan organik lebih tinggi dibandingkan lahan anorganik, suhu tanah yang tinggi dimungkinkan karena adanya proses dekomposisi pupuk organik yang dilakukan oleh fauna tanah. Kisaran suhu udara dan suhu tanah di kedua lahan yaitu $25-32^{\circ} \mathrm{C}$, dimana suhu tersebut merupakan kisaran suhu optimum dan toleran bagi semut untuk beraktivitas di daerah tropis (Riyanto, 2007).

Nilai derajat keasaman $(\mathrm{pH})$ tanah juga berpengaruh terhadap keberadaan semut. Nilai derajat keasaman di lahan orgnaik 6,2 dan anorganik 6,4. Lahan organik memiliki $\mathrm{pH}$ yang lebih asam dibandingkan dengan anorganik, hal ini dikarenakan adanya dekomposisi bahan organik yang menghasilkan asam asam dominan sehingga dapat menurunkan $\mathrm{pH}$. Nilai derajat keasaman yang ada di lahan organik dan anorganik masih dalam kisaran $\mathrm{pH}$ yang umum bagi fauna tanah, sehingga semut masih dapat beraktivitas (Riyanto, 2007).

Tabel 4. Faktor kimia tanah di lahan organik dan anorganik

\begin{tabular}{lcc}
\hline Unsur & Organik & Anorganik \\
\hline N-Total & 0.4 & 0.37 \\
C-Organik & 4.2 & 1.67 \\
Phospor & 75.6 & 57.8 \\
C/N & 107 & 4.3 \\
Bahan Organik & 7.4 & 3 \\
\hline
\end{tabular}

Tabel 4. Nilai t-hitung kandungan unsur makroesensial antara lahan pertanian organik dan anorganik

\begin{tabular}{|c|c|c|c|c|c|}
\hline & $\mathrm{C}$ & $\mathrm{N}$ & $\mathrm{P}$ & $\mathrm{BO}$ & $\begin{array}{l}\text { Rasio } \\
\text { C/N }\end{array}$ \\
\hline $\mathrm{C}$ & $5.59^{\mathrm{S}}$ & & & & \\
\hline $\mathrm{N}$ & & $1.01^{\mathrm{TS}}$ & & & \\
\hline $\mathrm{P}$ & & & $2.76^{\mathrm{S}}$ & & \\
\hline $\mathrm{BO}$ & & & & $5.57^{\mathrm{S}}$ & \\
\hline Rasio & & & & & $8.5^{\mathrm{S}}$ \\
\hline $\mathrm{C} / \mathrm{N}$ & & & & & \\
\hline
\end{tabular}

$\overline{\mathrm{TS} \text { :Tidak ada perbedaan signifikan antar unsur di kedua }}$ lahan

S : Terdapat perbedaan signifikan antar unsur di kedua lahan

Hasil perhitungan dari uji statistik didapatkan perbedaan unsur makroesensial di lahan pertanian organik dan anorganik. Secara statistik, kandungan karbon, fosfor, bahan organik dan rasio c/n di lahan organik dan anorganik terdapat perbedaan. Pupuk yang digunakan pada lahan pertanian organik berasal dari kotoran hewan ternak seperti ayam dan kambing, sedangkan pada lahan pertanian anorganik menggunakan pupuk urea. Menurut Musnamar (2007), kotoran ayam mengandung unsur hara lengkap yang dibutuhkan oleh tanaman untuk pertumbuhannya seperti nitrogen $(\mathrm{N})$, fosfor $(\mathrm{P})$, kalium $(\mathrm{K})$, kalsium $(\mathrm{Ca})$, Magnesium $(\mathrm{Mg})$ dan sulfur (S).

Proses dekomposisi dapat dilihat dari perbandingan unsur $\mathrm{C}$ dan $\mathrm{N}$ dalam tanah (rasio $\mathrm{C} / \mathrm{N}$ ). Tingginya rasio $\mathrm{C} / \mathrm{N}$ di lahan pertanian organik dikarenakan pupuk yang digunakan adalah pupuk kandang yang berasal dari kotoran ayam. Kotoran ayam memiliki kandungan unsur $\mathrm{C}$ yang lebih tinggi dibandingkan kandungan unsur $\mathrm{C}$ pada pupuk urea (Putra, 2015). Proses dekomposisi tergantung kegiatan mikroorganisme yang membutuhkan kandungan $\mathrm{C}$ dan $\mathrm{N}$ yang akan dimanfaatkan sebagai sumber energinya.

Lahan organik dan anorganik memiliki kandungan unsur $\mathrm{N}$ yang berbeda. Kotoran ayam berfungsi sebagai makanan dari mikroba tanah pengikat $\mathrm{N}$ yang ada di udara sehingga dapat meingkatkan kandungan unsur $\mathrm{N}$ yang ada di lahan organik (Sidabutar, 2006). Nitrogen merupakan unsur yang di perlukan makhluk hidup dalam kehidupannya, kadar nitrogen dibutuhkan 
mikroorganisme untuk memelihara dan pembentukan sel.

Bahan organik pada lahan organik lebih tinggi dibandingkan pada lahan anorganik. Penguraian bahan organik menjadi senyawasenyawa anorganik disebut mineralisasi, dimana proses juga dihasilkan unsur hara yang langsung dapat digunakan oleh tanaman (Tjwan, 1968). Keberadaan semut menyukai daerah yang memiliki kandungan bahan organik tinggi, hal ini dikarenakan dengan jumlah bahan organik yang tinggi, akan mempengaruhi keberadaan fauna tanah lain yang merupakan makanan bagi semut.

\section{KESIMPULAN}

Jumlah jenis dan jumlah individu semut pada lahan organik lebih tinggi dibandingkan dengan lahan anorganik. Indeks keanekaragaman dan kemerataan jenis semut pada lahan organik lebih tinggi dibandingkan lahan anorganik. Kesamaan jenis di lahan pertanian organik dan anorganik memiliki tingkat kesamaan jenis yang tinggi. Semut yang termasuk dalam kategori dominan di kedua lahan adalah Solenopsis geminata, Odontoponera denticulata, Tetramorium sp, Iridomyrmex sp dan Diacamma sp. Secara statistik, kandungan unsur yang berbeda pada kedua lahan adalah unsur karbon, fosfor, rasio $\mathrm{c} / \mathrm{n}$ dan bahan organik.

\section{DAFTAR PUSTAKA}

Fawzya, Y.N., S. Putri, N. Noriko. and G. Patantis, 2013. Identification of SGS 1609 Cellulolytic Bacteria Isolated from Sargassum spec. and Characterization of The Cellulase Produced. Squalen Bulletin of Marine \& Fisheries Postharvest \& Biotechnology. 8 (2): 57-68.

Hogg, S. 2005. Esential Microbiology. The University Of Glamorgan UK : John Wiley \&Sons L.td.

Haq, I.U., M.M. Javed, T.S. Khan and Z. Siddiq. 2005. Cotton Saccharifying Activity of Cellulase Produces by Co-culture of Aspergillus niger and Trichoderma viride. Res.J.Agric Boil. Sci. 1(3):241-245

Isaie, Mushimiyimana \& Padmavathi, Tallapragada. 2015. Agro wastes residues as strategy to produce cellulase. International J. Of Chemt Tech. 8: 89-97
Jahangeer, S., N. Khan., S. jahangeer., M. Sohail., S. Shahzad., A. Ahmad and S.A. Khan. 2005. Screening and Characterization of Fungal Cellulase Isolated From The Native Environmental Source. Pak J Bot 37 : 739748.

Ji W, D. Ming, L. Yan-Hong, C. Qing-Xi, X.GenJun, and Z. Fu-Kun, 2003. Isolation of a multifunctional endogenous cellulase gene from mollusc, Ampullaria crossean. Dalam : Al-Arif, M.A., W. Darmanto dan N.T. Puspaningsih, (eds.) 2012. Isolasi dan Karakterisasi Ensim Selulase dari Keong Emas dan Rayap sebagai Bahan Pendegradasi Selulosa. Jurnal JBP Biosains. 2(14) : 86-92.

Johnsen, H.R. and K. Krause, 2014. Cellulase Activity Screening Using Pure Carboxymethylcellulose:Application to Soluble Cellulolytic Samples and to Plant Tissue Prints. Int. J. Mol. Sci. 15: 830-838.

Khianngnam S,Y. Pootaeng-on, T. Techakriengkrai, S. Tanasupwat. 2014. Screening and Identification Of Cellulase Producing Bacteria Isolated From Oil Palm Meal. J. Appl. Pharmaceutical Sci. 4(04) : 090-096.

Lisdiyanti, P., E. Suyanto, N.F. Gusmawati, dan W. Rahayu, 2012. Isolation and Characterization of Cellulase Produced by Cellulolytic Bacteria from Peat Soil of Ogan Komering Ilir, South Sumatera. Int. J. Env. Bioenergy. 3(3): 145-153.

Madigan, M.T., J.M. Martinko, P.V. Dunlap, and D.P. Clark, 2012. Brock :Biology Of Microorganism. Pearson Benjamin Cummings, US.

Sreeja SJ, PW. Jeba Malar, J.F.R Sharmila, T. Steffi, G. Immanuel, and A. Palavesam. 2013. Optimization of cellulase production by Bacillus altitudinis APS MSU and Bacillus licheniformis APS2 MSU, gut isolates of fish Etroplus suratensis. IJOART. 2: 401-406.

Vyas, Ashish. D. Vyas and K.M. Vyas. 2005 Production and Optimization Of Cellulase On Pretreated Groundnut Shell By Aspergillus terreus AV49. J. Of Sci \& Industrial Research. 64: 281-286. 
Ivan Mahadika Putra, Mochamad Hadi dan Rully Rahadian 